\title{
Reducing the Negative Impact of Pop-up Advertisements on Users and Improving Potential Purchase Intention
}

\author{
Lana $\mathrm{Yi}^{*}$ \\ Loughborough University, London, United Kingdom \\ *Corresponding author: Lana Yi, lanayi66440@gmail.com
}

\begin{abstract}
With the development of the internet, online pop-up advertisements (hereinafter, referred to as pop-up ads) have emerged. However, online users may disdain and reject online advertisements, which affects online purchase intention. This study is on reducing the negative impact of pop-up ads on users and improving the commercial effect. Self-administered questionnaires were used to survey online users and website designers. The data collected were analyzed using SPSS and the open answers were sorted out by thematic analysis. The results revealed that attractive storylines, background music, and exquisite visual presentations are effective in reducing users' rejection to pop-up ads as well as advertisement customization. It is better for pop-up ads to appear in the middle or end of videos. The VIP system is also a choice for users to eliminate them. Designers are supposed to keep a balance between users and advertisers. In addition, internet regulation needs to be strengthened to reduce eroticism and violence in pop-up ads as well as avoid the negative impact of these kind of pop-up ads on minors.
\end{abstract}

Keywords: Pop-up advertisements; Websites; Online users; Designers; Advertisers; Purchase intention

Publication date: October 2021; Online publication: October 29, 2021

\section{Introduction}

In this era, along with the rapid growth of science and technology, there are abundant transmissible means, thus providing more media platforms for advertisers ${ }^{[1]}$. Online advertising began to appear in $1994{ }^{[2]}$. When users watch videos online, they accept various ads consciously or unconsciously. Online advertising can be mandatory or optional ${ }^{[1]}$. Pop-up ads are the most common form of intrusive advertising, and they affect users' online experiences. It is difficult to eliminate them completely ${ }^{[3,4]}$. Some websites even lack internet regulations. Research has found that the most unacceptable ads for consumers in the United States were pop-up ads from 13 different types of advertisements ${ }^{[5]}$. This study found effective ways to improve the quality of pop-up ads, reduce the negative influences on users, and improve the purchase intention.

\section{Literature review}

The internet is a dominant medium which inevitably provides marketing information ${ }^{[6]}$ and advertisements on websites ${ }^{[7]}$. Advertisers would try to catch the attention of users in various ways ${ }^{[8]}$. Online advertisements include pop-up ads; they may appear as small windows on the screen which interrupt users' experiences ${ }^{[5]}$. Advertisements can help consumers to make online purchasing decisions ${ }^{[9]}$. Dehghani and other researchers ${ }^{[10]}$ stated that ads on YouTube can stimulate users to purchase products or services. Online advertising which includes pop-up ads does promote purchase intentions. However, pop-up ads seem to have a controversial effect on users' experience. Pasqualotti and Baccino ${ }^{[8]}$ suggested for banner ads to be 
replaced by other kinds of ads, such as pop-up ads, which would be interesting and attractive. On the contrary, Le and $\mathrm{Vo}^{[1]}$ demonstrated through their research that the entertainment of pop-up ads is less than that of banner ads and insert ads. In addition, some users experience a feeling of intrusiveness, resulting in a negative impact on potential online consumers ${ }^{[11,12]}$. Le and $V_{0}{ }^{[1]}$ found that pop-up ads are the first, followed by in-line ads and banner ads in regard to users' emotional anger. Therefore, the features of popup ads that have positive and negative effects on users need to be further explored. At present, most studies have explored the impact of pop-up ads from the perspective of users, not web designers. Design is seen as a character with function and strategy in business ${ }^{[13]}$, and designers work closely with advertisers. One of the imperative aspects of successful website advertising is the visual design ${ }^{[14]}$. Therefore, this study discusses the negative impact of pop-up ads from the perspectives of designers and users in order to improve the potential purchase intention of users.

\section{Research methods}

Majority of the users who took part in the survey are between 18 and 39 years of age, and they are from China and Europe. As the young generation often watches pop-up ads, they are able to better understand the questions and may provide more effective suggestions. The questionnaire consists of closed, open, and semi-structured questions. The completion time of the process was less than 15 minutes. The survey was conducted using network questionnaires.

The questionnaire for designers was to understand the relevant rules in designing pop-up ads and to compare with the answers from the questionnaire for users in order to analyze the differences and provide solutions. The questionnaire was distributed online for investigation. The investigation time was around 15 minutes. The questionnaire for users received a total of 111 responses, of which 100 were valid. The second questionnaire for designers received 103 responses, of which 100 were valid. Some of the questions for the designers were more professional than those for the users; in addition, several open questions were added for the designers.

\section{Ethical issues}

All the participants agreed to take part in the study. The purpose and details of the study have been explained to all the participants. All information was stored safely and anonymously, and all the participants signed the informed consent statement.

\section{Results}

\subsection{Statistical analysis}

SPSS was used for statistical analysis, and it was found that $84 \%$ of the participants frequently experienced pop-up ads with $86 \%$ of participants disliking pop-up ads. $77 \%$ of them chose to skip those ads. More than half of the participants preferred pop-up ads to appear at the end of videos, thus having minimal impact on their online experience. However, the results showed that there were a few users who watch pop-up ads. This would influence the benefits of advertisers and website operations. $42 \%$ of the participants expressed that they were willing to pay to be VIP members in order to eliminate pop-up ads, while $47 \%$ were not and $11 \%$ were unsure. $11 \%$ of users claimed that they may be able to accept pop-up ads with a positive attitude if those ads are optimized. Only $19 \%$ of the participants would usually remember the pop-up ads they see, while $81 \%$ do not. Among those who remember, their answers were classified into four categories: movies, games, commodities, and food. However, in another research, it was found that the consumers were not able to recall any products from the pop-up ads seen ${ }^{[5]}$. It may be due to repetitions in advertisements or Chinese consumers are more willing to accept commercial contents ${ }^{[15]}$. 


\subsection{Thematic analysis}

Since the answers to the open questions in the questionnaire varied, thematic analysis was used to categorize and count the highest number of answers. Some of the answers had several sub-themes, so the total number of partial code count was more than 100. Each main theme has representative sub-themes, of which all have corresponding examples to record from the original answers of the participants as well as code counts.

\subsubsection{Users}

In terms of features of pop-up ads that users prefer, most answers were regarding "attractive storylines," followed by "background music," which is also a factor that users frequently consider. The remaining subthemes include "the product or service that users need" and "exquisite visual presentations." The factor that is most related to users' rejection is "unable to skip pop-up ads." This means that users would have to watch the pop-up ads in order to continue what they were doing. Moreover, "boring content" and "poor visual presentations" are also reasons why a large number of users reject these ads. Under the option of "others," there were a few unique opinions, such as "erotic ads content," "not interested in the advertised products," "the length of advertisements is too long," etc. In order to reduce users' rejection to pop-up ads, 24 participants suggested to "improve advertising quality," which has the highest proportion among the recommendations. Other suggestions include "skip pop-up ads," "shorten the length of pop-up ads," etc. In addition to that, 20 participants suggested that pop-up ads with novel storylines would help to increase potential purchase intention.

\subsubsection{Designers}

In comparison to the users' sub-themes, designers made more diversified suggestions. However, some of the suggestions have conflicts with the factors that influence users' rejection to pop-up ads, so they are not adopted.

Most designers felt that the problems found in pop-up ads are "poor visual presentations," followed by "affect online experiences of watching videos," and "lack of creativity." Other suggestions include "erotic and violence," "unreliable products and services," etc. The major requirement that designers need to follow is "exquisite visual presentations." The other requirements are "concise," "innovative," "understand users" needs," "close to reality," "humanized design," etc. Other answers were related to "business partner's satisfaction." Most designers suggested "interesting content and creativity" as the factor to reduce users' rejection to pop-up ads, followed by "products that users need." On the other hand, "advertisement customization" was recommended as the factor that can improve business effectiveness. In addition, several participants also suggested "membership system," "movie stars," etc.

\section{Conclusion}

In conclusion, in order to reduce the negative impact of pop-up ads on users and improve the commercial effects for advertisers, visual presentations and storylines should be strengthened. Advertisement customization is also an important factor to stimulate purchase intention. In addition, pop-up ads can be set to be played in the middle or end of videos, and users can be given the choice to selectively close the popup windows. In order to eliminate pop-up ads and have a better online experience, users can purchase VIP memberships as well. Pop-up ads are supposed to reduce erotic, violence, gambling, and other inappropriate content for children.

A certain number of users have a neutral attitude toward pop-up ads. If their online experience can be effectively improved with pop-up ads, it will be possible for these users to accept pop-up ads and raise their potential purchase intentions. Furthermore, designers need to balance the standards of advertisers' 
requirements and users' experience. Taking in consideration of all the above measures, the negative impact of pop-up ads on users can be reduced and the commercial effect of websites can be improved to a certain extent. This study has made several supportive suggestions for advertisers to promote products or services by pop-up ads as well as would help designers to better understand users' experience and the aspects that conflict with their views to balance the relationship between users and advertisers.

\section{Limitations and future research}

Several answers to the open-ended questions were distinct. They should be verified if they can improve users' online experience; for example, reducing the size of pop-up ads window. This can be investigated via a supplementary simulation experiment, such as the A/B test. In addition, users with different cultural backgrounds from Asia and Europe may have different views on pop-up ads. Future studies regarding this subject should emphasize on analyzing cross-cultural perspectives and the differences among different countries.

\section{Disclosure statement}

The author declares that there is no conflict of interest.

\section{References}

[1] Le T, Vo H, 2017, Consumer Attitude towards Website Advertising Formats: A Comparative Study of Banner, Pop-Up and In-Line Display Advertisements. Internet Marketing and Advertising, 11(3): 202-217.

[2] Briggs R, Hollis N, 1997, Advertising on the Web: Is There Response Before Click-Through?. Journal of Advertising Research, 37(2): 33-45.

[3] Chatterjee P, 2008, Are Unclicked Ads Wasted? Enduring Effects of Banner and Pop-Up Ad Exposures on Brand Memory and Attitudes. Journal of Electronic Commerce Research, 9(1): 51-61.

[4] McCoy S, Everard A, Polak P, et al., 2007, The Effects of Online Advertising. Communications of the ACM, 50(3): 84-88.

[5] Rehman M, Fakhar A, Siddiqui DA, 2021, Pop-Up AD - Hit or Miss?. SSRN. https://ssrn.com/abstract=3813312 or http://dx.doi.org/10.2139/ssrn.3813312 (accessed on September 24, 2021).

[6] Kaiser C, F Bodendorf, 2012, Mining Consumer Dialog in Online Forums. Internet Research, 22(3): 275-297.

[7] Hsieh A, Lo S, Chiu Y, 2016, Where to Place Online Advertisements?. Journal of Electronic Commerce Research, 17(1): 36-46.

[8] Pasqualotti L, Baccino T, 2014, Online Advertisement: How Are Visual Strategies Affected by the Distance and the Animation of Banners?. Frontiers in Psychology, 5(1): 1-11.

[9] Alwitt LF, Prabhaker PR, 1994, Identifying Who Dislikes Television Advertising: Not by Demographics Alone. Journal of Advertising Research, 34(6): 17-29.

[10] Dehghani M, Niaki MK, Ramezani I, et al., 2016, Evaluating the Iinfluence of YouTube Advertising for Attraction of Young Customers. Comput Hum Behav, 59: 165-172.

[11] Chowdhury HK, Parvin N, Weitenberner C, et al., 2006, Consumer Attitude Toward Mobile Advertising in an Emerging Market: An Empirical Study. International Journal of Mobile Marketing, 1(2): 33-42. 
[12] Doorn VJ, Hoekstra JC, 2013, Customization of Online Advertising: The Role of Intrusiveness. Marketing Letters, 24(4): 339-351.

[13] Bruce M, Daly L, 2007, Design and Marketing Connections: Creating Added Value. Journal of Marketing Management, 23(9-10): 929-953.

[14] Cho CH, 1999, How Advertising Works on the World Wide Web: Modified Elaboration Likelihood Model. Journal of Current Issues and Research in Advertising, 21(1): 33-49.

[15] Bai Y, Zhao X, Cocker H, 2017, Wechat Brands: Communal Interaction and Brand Publicity in Chinese Social Media. Advances in Consumer Research, 45: 511. 